\title{
RESPON PERTUMBUHAN BIBIT Gmelina arborea Roxb. TERHADAP PERLAKUAN MEDIA TANAM DAN BIOSTIMULAN DI PERSEMAIAN PERMANEN IPB
}

\author{
Response of Gmelina arborea Roxb. seedling growth to media planting and biostimulant \\ amendment in IPB permanent nursery
}

Johan Ariando Rajagukguk ${ }^{1 *}$, Yadi Setiadi ${ }^{2}$ Iwan Hilwan', Noor Faiqoh Mardatin ${ }^{3}$

(Diterima Maret 2017/Disetujui November 2018)

\begin{abstract}
Nursery activities were one important step in producing quality seedling. This study used a very low quality Gmelina seed with germination value of $9.8 \%$. This value affected the ability of plants in responding to treatment. Input technology of growing media treatment and biostimulan needed to improve the quality of seedling. Sample of media planting collected from IPB permanent nursery. Applications biostimulan was using to help increased amount of plant roots. This study used a completely randomized factorial design with 7 replications. Observations for 8 weeks after planting (MST) found the media's treatment plant and biostimulan has significant effect on the parameters of diameter, height and total dry weight compared to control. Compost was the best medium in this study who had the highest NPK value compared to other media. Biostimulan concentration of $4 \%$ was proved improving the quality of Gmelina seedling in all media by increased the compactness of the roots of seedlings. The percentage increased in root dry weight (BKA), the largest found in the media mix of compost and mud. The best treatment in improving the quality of seeds Gmelina found in compost media and biostimulan $4 \%$ on all parameters of growth.
\end{abstract}

Key words: biostimulant, root compaction, seedling quality

\section{PENDAHULUAN}

Berdasarkan data Kemenhut (2014), jumlah lahan kritis di Indonesia seluas 24.30 juta ha. Rehabilitasi dan reboisasi lahan telah dilakukan untuk mengatasi permasalahan lahan kritis. Dukungan ketersediaan benih dan bibit berkualitas sangat diperlukan untuk menunjang keberhasilan rehabilitasi lahan. Kegiatan persemaian merupakan salah satu tahapan penting dalam menghasilkan bibit berkualitas baik. Bibit yang berkualitas berpengaruh pada kemampuan tanaman beradaptasi dan bertahan pada kondisi lapangan (Mattson 1997, Jacobs et al. 2005). Bibit yang berkualitas dihasilkan dari benih bermutu baik yang ditinjau penampilan fisik (kadar air, kemurnian, dan Bobot benih) dan fisiologis (daya kecambah) sebagai parameter utama pengujian benih tersertifikasi (Sudrajat \& Nurhasby 2009). Benih yang tersertifikasi tidak selalu mampu memenuhi standar mutu benih yang telah disyaratkan. Hal ini ditemukan pada benih Gmelina yang diperoleh dari balai perbenihan tanaman hutan (BPTH) dan digunakan pada penelitian ini dengan persentase perkecambahan sangat rendah $(9,8 \%)$, jauh di bawah standar perkecambahan benih Gmelina $>70 \%$.

\footnotetext{
${ }^{1}$ Mahasiswa Pascasarjana PS. Silvikultur Tropika, Fakultas Kehutanan IPB

* Penulis korespondensi:

e-mail: johanariando@gmail.com

2 Staff Pengajar Dept. Silvikultur, Fakultas Kehutanan IPB

${ }^{3}$ Staf Peneliti Bioteknologi Hutan, PAU IPB
}

Penggunaan benih berkualitas rendah perlu penanganan khusus dalam meningkatkan kualitas bibit sehingga dapat memenuhi standar yang telah ditetapkan. Input teknologi pembenahan tanah diperlukan untuk menyediakan sumber nutrisi yang dibutuhkan tanaman. Penambahan kompos pada media lumpur terbukti meningkatkan jumlah biomassa mikroorganisme dan respirasi basal sehingga secara signifikan membantu pertumbuhan tanaman (Jones et al. 2012). Aplikasi biostimulan pada tanaman juga diperlukan untuk merangsang perakaran tanaman dalam mengakses sumber nutrisi pada tanah. Irwansyah (2015) menemukan pemberian biostimulan konsentrasi $4 \%$ pada tanaman Gmelina meningkatkan Bobot kering akar $32.000 \%$ dibandingkan dengan kontrol pada media tanam yang sama.

Tanaman Gmelina termasuk dalam pohon cepat tumbuh (fast growing species) dan telah dikenal aspek budidaya sehingga dikembangkan pada hutan tanaman industri (HTI) dan hutan rakyat karena memiliki nilai komersial tinggi (Kosasih \& Danu 2013). Penggunaan tanaman Gmelina dapat dijadikan alternatif dalam meningkatkan produktivitas lahan kritis sehingga diperlukan bibit berkualitas baik yang mampu bertahan di lapangan. Menurut BPTH (2014), bibit Gmelina ideal memiliki tinggi $\geq 30 \mathrm{~cm}$, diameter $\geq 4 \mathrm{~mm}$, dan jumlah daun $\geq 5$ dengan umur bibit $\geq 4$ bulan

Penelitian tentang pengaruh teknologi pembenahan tanah dan aplikasi biostimulan diperlukan untuk meningkatkan kualitas bibit Gmelina di persemaian sehingga dapat memenuhi standar BPTH (2014). 
Penelitian ini bertujuan untuk: (1) menguji respon tanaman terhadap perlakuan media tanam dan konsentrasi biostimulan. (2) menentukan kualitas mutu bibit berdasarkan indeks mutu bibit Dickson et al. (1960) dan Standar mutu bibit BPTH (2014). Manfaat penelitian ini adalah memberikan informasi terhadap penggunaan media tanam yang tepat pengaruh biostimulan dalam meningkatkan kualitas mutu bibit.

\section{METODE PENELITIAN}

\section{Waktu dan Tempat Penelitian}

Penelitian ini dilakukan di Laboratorium Bioteknologi Hutan Pusat Antar Universitas (PAU) IPB dan Persemaian Permanen Institut Pertanian Bogor (IPB) Dramaga pada bulan Juli 2016 - Oktober 2016. Tahap awal penelitian adalah mengecambahkan benih Gmelina di dalam bak kecambah yang berisi zeolit yang telah dicuci bersih. Pengamatan kecambah dilakukan selama 28 hari. Media tanam yang berasal dari areal persemaian permanen yaitu media tanam M1 (tanah), M2 (kompos), M3 (campuran kompos dan tanah) M4 (kompos dan lumpur) dimasukkan dalam polibag $(15 \times 20) \mathrm{cm}$. Perbandingan campuran media M3 dan M4 yaitu 1:1 berdasarkan bobot media $(\mathrm{g})$. Benih gmelina dengan ukuran seragam yang diamati secara visual dipindahkan ke dalam polibag yang telah dipisahkan berdasarkan media tanam dan dimasukkan ke dalam sungkup selama 3 hari untuk aklimatisasi benih. Setelah 3 hari, polibag dipindahkan ke bedengan di persemaian permanen yang telah dibersihkan dari tanaman pengganggu. Polibag diberikan biostimulan sesuai jenis perlakuan yaitu kontrol (tanpa pemberian biostimulan), konsentrasi $4 \%$ (1L biostimulan dicampur 25L air) dan konsentrasi 2\% (1L biostimulan dicampur 50L air) sebanyak $200 \mathrm{ml}$ sebanyak 2 kali yaitu awal dipindahkan dan 3 minggu setelah tanam (MST). Setiap polibag diberikan label nama berdasarkan jenis perlakuan media tanam dan biostimulan. Pemeliharaan dilakukan dengan pembersihan dari tanaman pengganggu dan menjaga tanah tetap lembab dengan penyiraman jika diperlukan. Perameter yang diamati selama penelitian yaitu tinggi bibit $(\mathrm{cm})$, diameter bibit (mm), Bobot kering pucuk (BKP), Bobot kering akar (BKA), indeks mutu bibit (IMB), ke kompakan akar dan analisis NPK media tanam. Rancangan percobaan yang digunakan pada penelitian ini adalah rancangan acak lengkap faktorial. Tanaman yang digunakan pada penelitian ini adalah Gmelina arborea Roxb. Penelitian ini terdiri dari 2 faktor yaitu faktor media tanam dan

Tabel 1 Rancangan percobaan penelitian

\begin{tabular}{lrcr}
\hline \multirow{2}{*}{ Biostimulan } & \multicolumn{3}{c}{ Jumlah Ulangan } \\
\cline { 2 - 4 } Media Tanam & $0 \%$ & $4 \%$ & $2 \%$ \\
\hline Tanah & 7 & 7 & 7 \\
Kompos & 7 & 7 & 7 \\
Kompos_Tanah & 7 & 7 & 7 \\
Kompos_Lumpur & 7 & 7 & 7 \\
\hline
\end{tabular}

aplikasi biostimulan. Jumlah ulangan pada masingmasing kombinasi perlakuan sebanyak 7 ulangan. Total satuan percobaan yang digunakan pada penelitian ini yaitu 84 satuan percobaan seperti ditunjukkan Tabel 1.

Analisis sidik ragam (ANOVA) yang digunakan adalah model rancangan percobaan Mattjik dan Sumertajaya (2002) dengan selang kepercayaan 95\%. Jika perlakuan berpengaruh nyata maka dilakukan uji lanjut Tukey. Analisis data dilakukan dengan menggunakan Minitab 16.

\section{HASIL DAN PEMBAHASAN}

\section{Perkecambahan Benih}

Kecepatan berkecambah dan banyaknya jumlah berkecambah berpengaruh pada kualitas bibit yang akan dihasilkan. Berdasarkan Tabel 2 diketahui persentase kecambah yang diamati selama 28 hari dikategorikan sangat rendah yaitu sebesar 9.8\%. Nilai ini jauh lebih rendah dari standar mutu fisik dan fisiologis benih sebesar 70\% (Dirjen BTPH 2014).

Penggunaan bibit berkualitas rendah menjadi salah satu penyebab kegagalan rehabilitasi lahan karena tidak dapat beradaptasi pada kondisi lapangan. Penelitian ini menggunakan benih Gmelina dengan persentase perkecambahan $9,8 \%$ yang dapat dikategorikan bibit jelek dan akan menurunkan kemampuan bibit merespon perlakuan yang diberikan. Input teknologi pembenahan tanah dan biostimulan yang telah dilakukan memberikan pengaruh yang signifikan dalam meningkatkan pertumbuhan tanaman. Pengamatan pertumbuhan bibit selama 8 minggu setelah tanam (MST) menunjukkan diameter dan tinggi bibit Gmelina dengan perlakuan media M2, M3, dan M4 diberikan biostimulan konsentrasi $4 \%$ mampu melebihi standar parameter pertumbuhan yang telah ditetapkan berdasarkan Standar BPTH (2014) dan indeks mutu bibit (IMB) Dickson (1960) .

\section{Analisis NPK pada Media Tanam}

Ketersediaan unsur hara makro berupa nitrogen, fosfor, dan kalium (NPK) pada media tanam sangat penting untuk mendukung pertumbuhan tanaman. Gmelina. Hasil analisis tanah menunjukkan bervariasinya kandungan unsur hara NPK pada berbagai perlakuan media tanam seperti ditunjukkan Tabel 3 . Perbedaan kandungan hara pada media tanam mempengaruhi ketersediaan nutrisi yang dapat diakses oleh akar tanaman sehingga menentukan pertumbuhan tanaman. Unsur N dan P pada media M1 (tanah) dikategorikan dalam kelas rendah berdasarkan kriteria sifat kimia tanah menurut Hardjowigeno (2010). Hal ini sejalan dengan data parameter pertumbuhan tanaman

Tabel 2 Persentase kecambah

\begin{tabular}{ccc}
\hline $\begin{array}{c}\text { Jumlah Benih } \\
\text { (biji) }\end{array}$ & $\begin{array}{c}\text { Jumlah } \\
\text { Kecambah (biji) }\end{array}$ & $\begin{array}{c}\text { Daya Berkecambah } \\
(\%)\end{array}$ \\
\hline 1000 & 98 & $9,8 \%$ \\
\hline
\end{tabular}


terbaik yang ditunjukkan pada bibit tanaman M2 dan bibit yang ditanam pada media M1 memiliki parameter pertumbuhan terendah. Tabel 2 menunjukkan media M1, M2, M3, M4 memiliki kandungan NPK yang relatif sama namun pada pengamatan di akhir penelitian ditemukan perbedaan yang signifikan antara tanaman kontrol dengan tanaman yang diberikan biostimulan $4 \%$.

\section{Parameter Pertumbuhan Bibit}

Parameter tinggi dan diameter bibit Gmelina diamati selama 8 MST. Berdasarkan analisis sidik ragam maka perlakuan media tanam dan biostimulan berpengaruh nyata pada parameter tinggi dan diameter bibit namun interaksi antar perlakuan tidak berpengaruh nyata seperti ditampilkan pada Tabel 4. Pertumbuhan bibit Gmelina memiliki perbedaan yang signifikan berdasarkan parameter tinggi dan diameter seperti ditunjukkan grafik pada Gambar 1. Adanya perbedaan nyata antara perlakuan media tanam dan biostimulan pada parameter tinggi dan diameter bibit maka perlu diuji lanjut menggunakan uji lanjut Tukey pada taraf $\alpha$ $=0,05$. Hasil uji lanjut pada perlakuan media tanam dan

Tabel 3 Analisis NPK media tanam dan Penentuan kriteria kimia tanah berdasarkan Hardjowigeno (2010)

\begin{tabular}{cccc}
\hline Perlakuan & $\mathrm{N}(\%)$ & $\mathrm{P}(\mathrm{ppm})$ & $\mathrm{K}(\mathrm{ppm})$ \\
\hline M1B1 & $0.18(\mathrm{R})$ & $13.95(\mathrm{R})$ & $151.29(\mathrm{ST})$ \\
M1B2 & $0.16(\mathrm{R})$ & $12.50(\mathrm{R})$ & $231.29(\mathrm{ST})$ \\
M1B3 & $0.16(\mathrm{R})$ & $10.14(\mathrm{R})$ & $141.20(\mathrm{ST})$ \\
M2B1 & $1.00(\mathrm{ST})$ & $437.68(\mathrm{ST})$ & $1134.64(\mathrm{ST})$ \\
M2B2 & $1.01(\mathrm{ST})$ & $437.86(\mathrm{ST})$ & $932.92(\mathrm{ST})$ \\
M2B3 & $1.07(\mathrm{ST})$ & $440.94(\mathrm{ST})$ & $1008.57(\mathrm{ST})$ \\
M3B1 & $0.40(\mathrm{~S})$ & $116.12(\mathrm{ST})$ & $706.00(\mathrm{ST})$ \\
M3B2 & $0.40(\mathrm{~S})$ & $93.48(\mathrm{ST})$ & $781.64(\mathrm{ST})$ \\
M3B3 & $0.43(\mathrm{~S})$ & $89.13(\mathrm{ST})$ & $756.43(\mathrm{ST})$ \\
M4B1 & $0.47(\mathrm{~S})$ & $87.14(\mathrm{ST})$ & $206.86(\mathrm{ST})$ \\
M4B2 & $0.59(\mathrm{~T})$ & $132.43(\mathrm{ST})$ & $554.72(\mathrm{ST})$ \\
M4B3 & $0.62(\mathrm{~T})$ & $196.56(\mathrm{ST})$ & $806.56(\mathrm{ST})$ \\
\hline
\end{tabular}

Ket: $\mathrm{M} 1=$ Tanah, $\mathrm{M} 2=$ Kompos, M3 $=$ Tanah+Kompos, $\mathrm{M} 4=$ Kompos+Lumpur, B1= kontrol, B2= konsentrasi $4 \%$, $\mathrm{B} 3=$ konsentrasi $2 \%, \mathrm{R}=$ rendah, $\mathrm{S}=$ sedang, $\mathrm{T}=$ tinggi, $\mathrm{ST}=$ sangat tinggi.

Tabel 4 Analisis sidik ragam perlakuan media tanam dan biostimulan terhadap pertumbuhan diameter dan tinggi tanaman

\begin{tabular}{lccc}
\hline Parameter & \multicolumn{2}{c}{ Perlakuan } & \\
\cline { 2 - 3 } & $\begin{array}{c}\text { Media } \\
\text { Tanam }\end{array}$ & Biostimulan & Interaksi \\
\hline Diameter & $*$ & $*$ & tn \\
Tinggi & $*$ & $*$ & tn \\
\hline
\end{tabular}

Ket : perbandingan nilai tengah berdasarkan taraf $\alpha=0,05$,

$*=$ berpengaruh nyata, $\mathrm{tn}=$ berpengaruh tidak nyata, $\mathrm{R}-\mathrm{sq}$ $($ diameter $)=78,13 \%, \mathrm{R}$-sq $($ tinggi $)=90,87 \%$. biostimulan didapatkan hasil perlakuan terbaik pada penelitian ini adalah perlakuan media tanam kompos dan penggunaaan aplikasi biostimulan $4 \%$.

Perbedaan parameter diameter dan tinggi tanaman berhubungan dengan ketersediaan hara pada tanah. Tabel 2 menunjukkan bahwa kandungan hara makro NPK pada media M2 hampir 10 kali lipat dibandingkan M1. Hal ini terlihat pada bibit M2 tanpa perlakuan biostimulan memiliki perbedaan diameter dan tinggi sebesar $>150 \%$ dibandingkan bibit yang ditanam pada media M1. Perlakuan biostimulan pada media M1 menunjukkan perbedaan yang signifikan yaitu bibit yang diberikan biostimulan konsentrasi $2 \%$ dan konsentrasi $4 \%$ meningkatkan pertumbuhan diameter dan tinggi tanaman berturut turut sebesar $>23 \%$ dan $>75 \%$ dan dibandingkan bibit tanpa perlakuan biostimulan.

Grafik tinggi bibit pada Gambar 1(b) menunjukkan penambahan biostimulan berpengaruh nyata pada pertumbuhan tinggi tanaman dengan media tanam kompos dan aplikasi biostimulan 4\% menjadi media tanam terbaik. Hal ini sejalan dengan nilai unsur hara NPK pada media M2 paling tinggi dibandingkan dengan media lainnya. Pemberian biostimulan konsentrasi $4 \%$ membantu meningkatkan diameter bibit $9 \%$ dan tinggi bibit $13 \%$ dibandingkan dengan tanaman kontrol pada media M2.
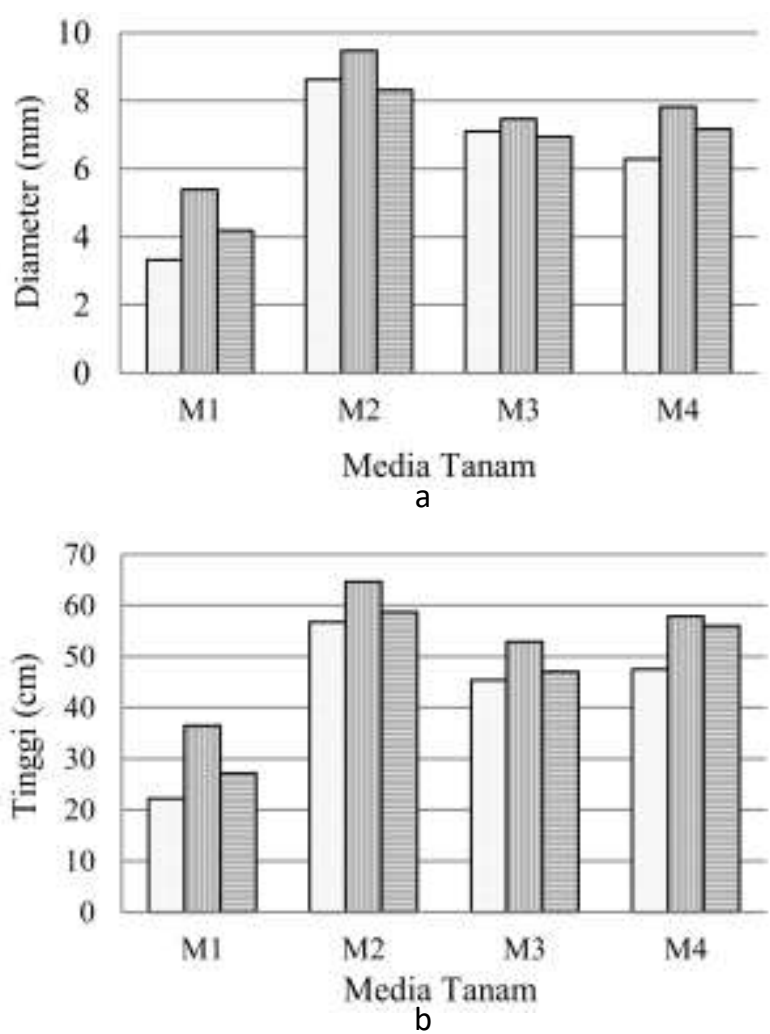

Ket: Media tanam $(M 1=$ tanah, M2= Kompos, M3=

Tanah+Kompos, M4= Kompos+Lumpur), Biostimulan $(\because \cdot=$ kontrol, $\|I\|=4 \%, \bar{\equiv}=2 \%)$

Gambar 1 Pengaruh penambahan biostimulan pada berbagai media tanam terhadap penambahan (a) diameter bibit, (b) tinggi bibit 
Berdasarkan grafik diameter dan tinggi bibit pada Gambar 1 pada media M4 perlakuan biostimulan konsentrasi $4 \%$ memiliki nilai diameter $9 \%$ lebih besar dan nilai tinggi bibit $3 \%$ lebih tinggi dibandingkan bibit M4 dengan perlakuan biostimulan 2\% namun data hasil analisis tanah di Tabel 2 menunjukkan nilai hara makro essensial NPK media M4 pada konsentrasi $2 \%$ lebih tinggi dibandingkan bibit M4 dengan konsentrasi $4 \%$. Pengaruh pemberian konsentrasi biostimulan yang lebih pekat menyebabkan peningkatan jumlah perakaran tanaman yang mempengaruhi meningkatnya kapasitas tanaman dalam menyerap hara yang tersedia pada media M4 seperti ditunjukkan pada nilai Bobot kering akar yang lebih besar. Jika dibandingkan bibit yang mendapat kombinasi perlakuan terbaik yaitu pemberian biostimulan konsentrasi $4 \%$ dan media M2 yang memiliki unsur hara makro essensial berdasarkan kriteria sifat kimia tanah dikategorikan sangat tinggi dengan bibit tanpa pemberian biostimulan dan media $\mathrm{M} 1$ yang termasuk kategori hara $\mathrm{N}$ dan $\mathrm{P}$ rendah maka ditemukan perbedaan diameter dan tinggi yang sangat besar yaitu $>180 \%$. Hasil pengukuran parameter tinggi dan diameter bibit Gmelina pada 8 MST di media M2, M3, dan M4 telah memenuhi standar mutu bibit BPTH (2014) yaitu tinggi $\geq 30 \mathrm{~cm}$, diameter $\geq 4 \mathrm{~mm}$ dan jumlah daun $\geq 5$ sedangkan pada media M1 hanya perlakuan biostimulan $4 \%$ yang memenuhi standar mutu bibit..

\section{Bobot kering akar dan tajuk}

Perlakuan media tanam dan pemberian biostimulan meningkatkan ketersediaan unsur hara untuk diakses oleh tanaman. Akar menyerap nutrisi dari media tanam dan mentransformasikan ke bagian pucuk tanaman. Perbedaan unsur hara yang tersedia bagi tanaman mempengaruhi pembentukan bagian tanaman seperti akar, batang, dan daun. Hasil uji sidik ragam perlakuan media tanam dan biostimulan menunjukkan adanya pengaruh nyata terhadap bobot kering akar (BKA) dan bobot kering pucuk (BKP) seperti ditunjukkan oleh Tabel 5.

Bobot akar dan pucuk dipengaruhi oleh perbedaan nutrisi hara pada media tanam dan perlakuan pemberian biostimulan pada bibit tanaman. Perlakuan media tanam yang berbeda dalam kandungan haranya seperti ditunjukkan oleh Tabel 2 mempengaruhi perbedaan bobot kering tanaman. Perbedaan kandungan hara NPK media M2 yang memiliki 10 kali lipat dibandingkan

Tabel 5 Analisis sidik ragam perlakuan media tanam dan biostimulan terhadap bobot kering akar dan bobot kering pucuk

\begin{tabular}{lccc}
\hline & \multicolumn{2}{c}{ Perlakuan } & \\
\cline { 2 - 3 } Parameter & $\begin{array}{c}\text { Media } \\
\text { Tanam }\end{array}$ & Biostimulan & Interaksi \\
\hline Bobot & $*$ & $*$ & tn \\
$\begin{array}{l}\text { kering } \\
\text { pucuk }\end{array}$ & $*$ & $*$ & tn \\
$\begin{array}{l}\text { Bobot } \\
\text { kering akar }\end{array}$ & $*$ & & \\
\hline
\end{tabular}

Ket: perbandingan nilai tengah berdasarkan taraf $\alpha=0,05$, $*=$ berpengaruh nyata, $\mathrm{tn}=$ berpengaruh tidak nyata, $\mathrm{R}$-sq $(\mathrm{BKP})=75,28 \%, \mathrm{R}-\mathrm{sq}(\mathrm{BKA})=56,26 \%$. media M1 mempengaruhi perbedaan BKA dan BKP sebanyak $500 \%$ dan $1052 \%$ tanpa pemberian biostimulan.

Perlakuan media kompos dan aplikasi biostimulan konsentrasi $4 \%$, merupakan perlakuan terbaik dalam penelitian ini seperti ditunjukkan oleh Gambar 2. Perlakuan terbaik menghasilkan $1237 \%$ BKP dan $824 \%$ BKA lebih bobot dibandingkan perlakuan M1 tanpa pemberian biostimulan. Hasil ini konsisten dengan parameter pertumbuhan diameter dan tinggi seperti ditunjukkan pada Gambar 1. Pengaruh biostimulan konsentrasi $4 \%$ dalam meningkatkan bobot BKP dan BKA terjadi secara konsisten pada bibit gmelina dibandingkan dengan kontrol pada media M1, M2, M3, dan M4 seperti ditunjukkan Gambar 2. Uji lanjut Tukey yang dilakukan pada bibit dengan perlakuan biostimulan konsentrasi $4 \%$ dan kontrol memberikan perbedaan yang signifikan. Rata-rata perbedaan BKA pada bibit dengan perlakuan biostimulan konsentrasi 4\% dan bibit kontrol pada berbagai media M1, M2, M3, dan M4 berturut turut sebesar 109\%, 54\%, 70\%, dan $131 \%$ sedangkan pada parameter BKP pada media M1, M2, M3, dan M4 berturut turut sebesar 226\%, $16 \%$, $35 \%$ dan $74 \%$.

Pengaruh biostimulan konsentrasi $4 \%$ terbukti meningkatkan perakaran bibit gmelina pada media tanam yang memiliki kandungan hara relatif sama seperti ditunjukkan data BKA pada Gambar 2. Semakin
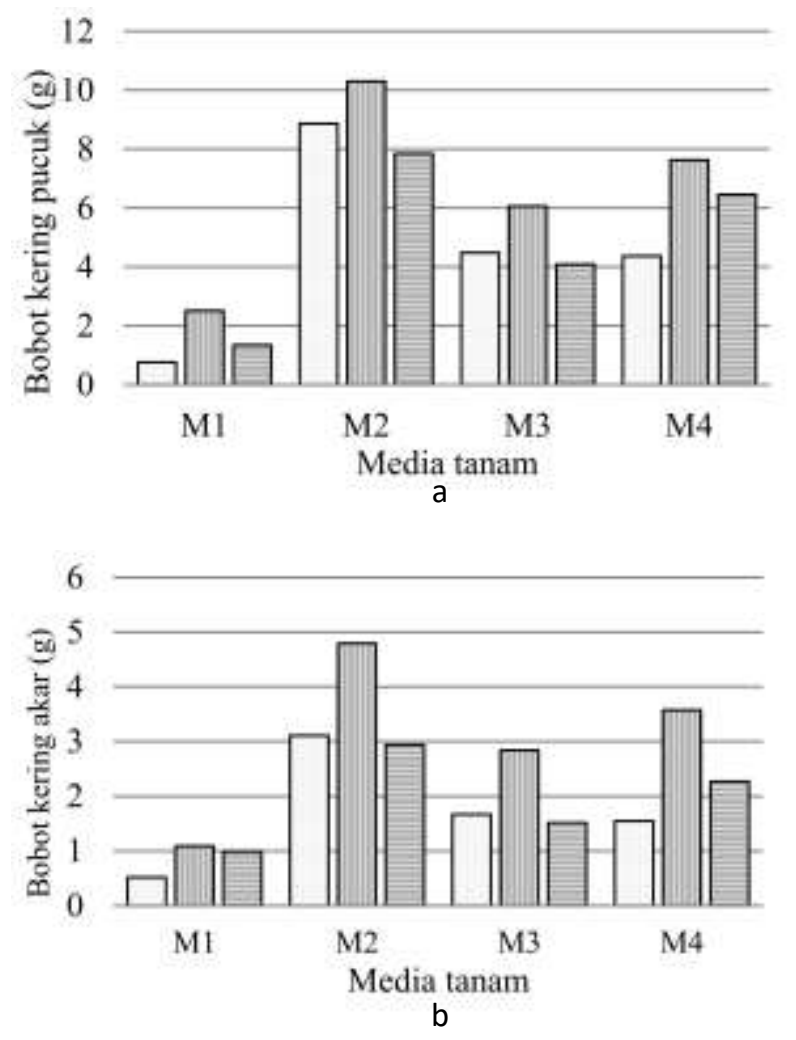

Ket: Media tanam $(\mathrm{M} 1=$ tanah, M2= Kompos, M3= Tanah+Kompos, M4= Kompos+Lumpur), Biostimulan ( $\therefore$. = kontrol, $\| \mathrm{II}=4 \%$, $=2 \%$ )

Gambar 2 Pengaruh penambahan biostimulan pada berbagai media tanam terhadap penambahan (a) bobot kering pucuk, (b) bobot kering akar 
banyak jumlah perakaran tanaman meningkatkan kemampuan tanaman dalam mengakses hara dari dalam tanah sehingga meningkatkan kualitas mutu bibit yang akan dipindahkan ke lapangan. Penggunaan biostimulan konsentrasi $4 \%$ pada media M1 (tanah) yang memiliki unsur hara $\mathrm{N}$ dan $\mathrm{P}$ dalam kategori rendah meningkatkan secara signifikan BKA (109\%) dan BKP (226\%) dibandingkan kontrol. Rasio BKA terbesar ditemukan pada bibit dengan media M4 yaitu lumpur. Hal ini disebabkan oleh campuran lumpur dan kompos dibantu pemberian biostimulan mengaktidkan akar yang menyediakan ekosistem yang baik dalam menguraikan hara menjadi tersedia bagi tanaman. Perlakuan biostimulan konsentrasi $4 \%$ yang meningkatkan pertumbuhan secara dapat menjadi alternatif solusi dalam meningkatkan kemampuan bibit pada lahan kritis dengan keberadaan hara rendah.

\section{Kualitas Mutu Bibit}

Penilaian kualitas mutu bibit yang digunakan pada penelitian ini menggunakan indeks mutu bibit (IMB) yang memberikan hasil yang konsisten bila dibandingkan parameter lainnya seperti rasio pucuk akar.

IMB dihitung dari rasio bobot kering total (BKT) dengan penjumlahan rasio tinggi dan diameter dan rasio pucuk akar. Dickson (1960) melakukan pengujian untuk mengelompokkan klasifikasi bibit pinus di persemaian ke dalam kelas jelek, sedang dan baik dan menetapkan nilai IMB >0.9 ke dalam kelompok bibit kategori baik. Semakin tinggi nilai indeks mutu bibit yang didapat maka semakin baik kualitas kelompok bibit yang dihasilkan di areal persemaian. Penggunaan tanah untuk media tanam tidak cocok dalam mendapatkan bibit berkualitas. Unsur hara $\mathrm{N}$ dan $\mathrm{P}$ yang rendah berdasarkan hasil analisis tanah menyebabkan tanaman tidak mendapatkan nutrisi yang cukup untuk pertumbuhan bibit. Penggunaan biostimulan konsentrasi 4\% yang membantu secara signifikan pada media M1 tidak mampu memenuhi standar IMB $>0.9$. Pemberian biostimulan konsentrasi $4 \%$ pada bibit gmelina membantu memenuhi standar kualitas bibit baik di media M3 dan M4 seperti ditunjukkan Gambar 3. Media kompos (M2) merupakan media tanam terbaik dalam penelitian ini karena memberikan nilai IMB melebihi standar dikarenakan kompos memiliki sumber hara terbaik berdasarkan data analisis tanah pada Tabel 2 .

\section{Kekompakan Akar}

Kekompakan akar menjadi salah satu parameter yang perlu dinilai secara deskriptif untuk menentukan kualitas bibit yang akan dipindahkan ke lapangan. Akar dikategorikan kompak jika akar dan media tanam membentuk gumpalan yang kompak. Hasil analisis kekompakan akar tanaman pada berbagai kondisi perlakuan ditunjukkan pada Tabel 5. Kekompakan akar sangat berhubungan dengan kemampuan tanaman dalam menyerap unsur hara yang tersedia pada media tanam. Semakin kompak perakaran tanaman maka pertumbuhan tanaman semakin baik. Hal ini terlihat pada parameter diameter, tinggi, bobot kering dan indeks mutu bibit. Pemberian biostimulan dengan konsentrasi $4 \%$ telah terbukti meningkatkan kekompakan akar berdasarkan data Tabel 5 pada media M2, M3, dan M4.

Tabel 6 Analisis deskriptif kekompakan akar

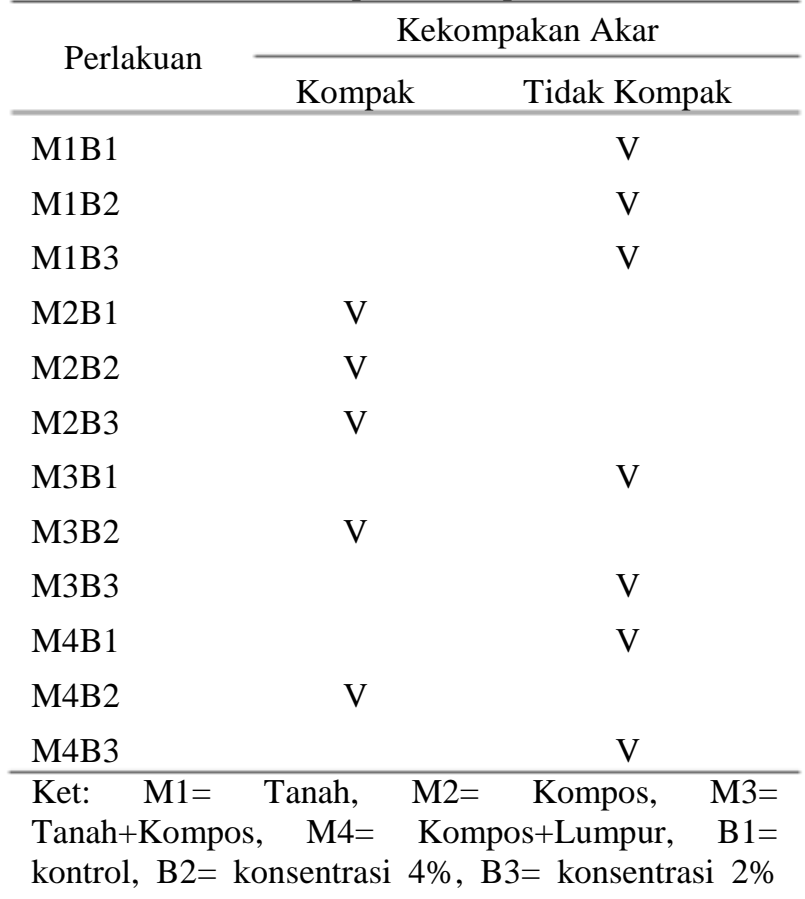

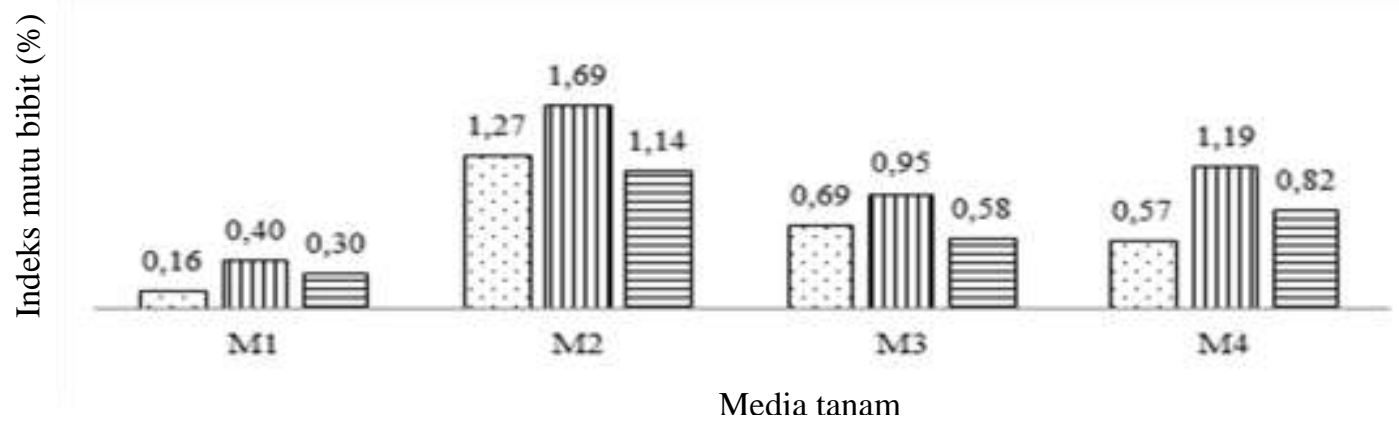

Ket: Media tanam $(M 1=$ tanah, M2= Kompos, M3= Tanah + Kompos, M4= Kompos+Lumpur $)$, Biostimulan

$(\because \therefore=$ kontrol, $\|||||||=4 \%, \overline{\bar{\equiv}}=2 \%)$

Gambar 3 Pengaruh Media Tanam dan Biostimulan terhadap Indeks Mutu Bibit 


\section{SIMPULAN DAN SARAN}

\section{Simpulan}

Parameter perkecambahan sebesar $9.8 \%$ benih gmelina yang digunakan dapat dikategorikan sebagai benih yang tidak layak untuk kegiatan pembibitan. Teknologi perlakuan media tanam dan aplikasi biostimulan pada benih bermutu sangat rendah terbukti mampu memenuhi standar mutu bibit ideal Balai Perbenihan Tanaman Hutan (BPTH) dan melebihi nilai IMB > 0.9. Hasil uji sidik ragam pada berbagai parameter pengukuran menunjukkan perlakuan media tanam dan aplikasi biostimulan berpengaruh nyata terhadap respon pertumbuhan namun interaksi antar perlakuan tidak berpengaruh nyata karena pemberian biostimulan konsentrasi $2 \%$ tidak berbeda dengan tanaman kontrol pada media M2 dan M3. Perlakuan media tanam kompos dan aplikasi biostimulan $4 \%$ memiliki kualitas mutu bibit terbaik ditinjau dari parameter diameter, tinggi dan bobot kering tanaman. Pengamatan kekompakan akar secara deskriptif membuktikan pemberian biostimulan $4 \%$ berpengaruh terhadap kekompakan akar pada semua media. Penggunaan lumpur sebagai campuran media tanam menjadi alternatif pembenah tanah memiliki pertumbuhan yang lebih baik dibandingkan dengan campuran media tanah dan kompos jika diberikan bantuan biostimulan.

\section{Saran}

Penelitian tentang penggunaan benih Gmelina dengan nilai perkecambahan sangat rendah $(9.8 \%)$ dengan menggunakan perlakuan media kompos dan biostimulan konsentrasi $4 \%$ yang telah terbukti memenuhi standar mutu kualitas bibit menurut BPTH (2014). Pengujian lanjutan tentang respon perlakuan kompos dan biostimulan konsentrasi $4 \%$ perlu dibandingkan dengan penggunaan benih bermutu rendah $(<70 \%)$ dan benih bermutu berdasarkan standar BPTH sebesar $70 \%$. Pengujian benih tanaman kehutanan lainnya dengan mutu benih rendah perlu dilakukan dengan perlakuan yang sama dan dibandingkan dengan bibit dengan nilai perkecambahan sesuai standar mutu benih untuk mengetahui pengaruhnya dalam memenuhi standar mutu bibit BPTH (2014).

\section{DAFTAR PUSTAKA}

[BPTH] Balai Perbenihan Tanaman Hutan. 2014. Standar mutu fisik fisiologis benih dan mutu bibit tanaman hutan. Bogor (ID): Direktorat Balai Perbenihan Tanaman Hutan.

[Kemenhut] Kementerian Kehutanan. 2014. Statistik Kehutanan tahun 2014. Bogor (ID): Kementerian Kehutanan.

Dickson A, Leaf AL, Hosner JF. 1960. Quality appraisal of white spruce and white pine seedling stock in nurseries. The Forestry Chronicle. 36(1): 1013, https://doi.org/10.5558/tfc36010-1.

Hardjowigeno S. 2010. Ilmu Tanah. Jakarta (ID): Akademika Pr.

Irwansyah A. 2015. Respon pertumbuhan bibit Gmelina arborea Roxb. dan Tectona grandis Linn.F. terhadap penambahan growth stimulant di persemaian permanen IPB [tesis]. Bogor (ID): Institut Pertanian Bogor.

Jacobs DF, Salifu KF, Seifert JR. 2005. Relative contribution of initial root and shoot morphology in predicting field performance of hardwood seedlings. New Forests. 30: 235-251.

Kosasih AS, Danu. 2013. Manual budidaya jati putih (Gmelina arborea Roxb.). Pusat Penelitian dan Pengembangan Peningkatan Produktivitas Hutan. Bogor (ID): Balai Penelitian dan Pengembangan Kehutanan.

Mattsson A. 1997. Predicting field performance using seedling quality assessment. New Fores. 13:227252.

Mattjik AA, Sumertajaya IM. 2002. Perancangan Percobaan dengan Aplikasi SAS dan Minitab. Bogor (ID): IPB Press.

Sudrajat DJ, Nurhasybi. 2009. Penentuan standar mutu fisik dan fisiologis benih tanaman hutan. Bogor (ID): Balai Penelitian Teknologi Perbenihan Bogor. Info Benih No. 13 (1): 147-158. 